\title{
Determining the optimal location of an urban transport interchange hub
}

\author{
Anton Erlikh * iD, Natalia Erlikh iD
}

Samara State Transport University, Samara, Russia

https://doi.org/10.54139/revinguc.v28i3.42

Abstract.- Several possible options for the location of Pyatiletka transport interchange hub in the Samara city district are considered. In order to determine the optimal option, the hub location is compared by several parameters. Such values as passenger traffic, existing routes of urban public transport, priority directions of passenger traffic, and capital investments in construction are selected as optimization parameters. To determine the values of passenger traffic, an analysis of the existing passenger traffic was performed, with its allocation by capacity and routing. The unevenness of passenger traffic by days of the week and periods of the day is determined, the minimum and maximum values of passenger traffic are revealed, as well as its fluctuations over the considered periods. The construction of public urban transport routes allowed to identify the busiest routes and the availability of transport for different options of the transport interchange hub location. The options of organizing the possible arrival/departure of urban public transport to/from the transport interchange hub are considered. Using the obtained data, a SWOT analysis was performed to determine the strengths and weaknesses of each hub placement option and the optimal option was selected.

Keywords: Passenger Traffic; SWOT Analysis; System Analysis; Transport Interchange Hub; Unevenness of Passenger Traffic.

\section{Determinación de la ubicación óptima de un centro de intercambio de transporte urbano}

Resumen.- Se consideran varias opciones posibles para la ubicación del centro de intercambio de transporte de Pyatiletka en el distrito de la ciudad de Samara. Para determinar la opción óptima, la ubicación del concentrador se compara con varios parámetros. Valores como el tráfico de pasajeros, las rutas existentes de transporte público urbano, las direcciones prioritarias del tráfico de pasajeros y las inversiones de capital en la construcción se seleccionan como parámetros de optimización. Para determinar los valores del tráfico de pasajeros se realizó un análisis del tráfico de pasajeros existente, con su asignación por capacidad y enrutamiento. Se determina el desnivel del tráfico de pasajeros por días de la semana y períodos del día, se revelan los valores mínimos y máximos del tráfico de pasajeros, así como sus fluctuaciones en los períodos considerados. La construcción de rutas de transporte público urbano permitió identificar las rutas más transitadas y la disponibilidad de transporte para diferentes opciones de la ubicación del centro de intercambio de transporte. Se consideran las opciones de organizar la posible llegada/salida del transporte público urbano hacia/desde el centro de intercambio de transporte. Utilizando los datos obtenidos, se realizó un análisis FODA para determinar las fortalezas y debilidades de cada opción de ubicación del concentrador y se seleccionó la opción óptima.

Palabras clave: Tráfico de pasajeros; Análisis FODA; Análisis del sistema; Centro de intercambio de transporte; Desigualdad del tráfico de pasajeros.

Received: October 28, 2021.

Accepted: December 09, 2021.

\section{Introduction}

The current stage of urban infrastructure development is characterized by an increase in the

\footnotetext{
* Correspondence author:

e-mail.7000anton@bk.ru(A.Erlikh)
}

park of personal vehicles. Almost all residents of the Russian Federation cities prioritize the use of personal vehicles, as it is convenient, comfortable, but not always practical [1]. A large number of cars leads to an increase in the load on the road network of cities and a significant reduction in its capacity. In this regard, municipalities are developing measures to encourage urban residents to abandon their personal cars and use public transport [2]. This is especially relevant for large 
investments in construction:

$$
z=f\left(K \_m, z \_e k s p l, K \_s n o s, K \_d o r\right) \rightarrow \min
$$

as well as limited availability zones for personal vehicle [3]. At the same time, public transport is actively developing in the city, intercepting parking lots are being arranged at the entrance to the city, transport interchange hubs are being built. This situation is typical not only for Moscow, but also for other Russian cities with a population of more than 1 million inhabitants, which includes the Samara city district. Public transport routes are being optimized in the city, it is being updated, and the construction of transport interchange hubs is planned. It is planned that in 2022, a transport interchange hub (TIH) will be built at the station. The transport interchange hub will be a kind of gate of the city. Passengers from Samara will be able to come to the TIH on commuter trains and suburban buses, as well as residents of the microdistricts Krutye klyuchi, Koshelev-Park and residents of the city of Togliatti. At this hub, passengers will be able to quickly transfer from one type of transport to another, as it is planned to create a TIH with access to the metro station, suburban electric trains, suburban buses. When solving this optimization problem, the question arises about the optimal location of the TIH.

\section{Methodology}

The issue of the optimal location of the transport interchange hubs in the urban environment is one of the most important issues in economic and social terms, i.e. convenience and attractiveness for passengers, which is to be solved before design and construction. Such issues are currently actively considered in the works of both domestic and foreign researchers [4, 5, 6, 7, 8, 2, 9, 10, 11, 12].

In fact, when deciding the optimal location of the TIH, it is necessary to analyze and consider a number of factors. The mathematical formulation of the problem can be written in finding the optimal values using the formula equation (1) determining the optimal location of the TIH according to the criterion of minimizing
When determining the optimal location of the $\mathrm{TIH}$, it is necessary to consider the optimization of functions (K_m)- capital investment in the construction of the TIH, z_ekspl- operating costs for the maintenance of the TIH devices, K_snoscosts for preparing the site for further construction of the TIH, K_dor- capital costs for the construction and design of entrances and roads to the TIH. From the given equation (1) function, it follows that the choice of the location of the TIH should be considered in order to minimize the investments in the construction and installation of the TIH. At the same time, the projected TIH should be located at the point of maximum intersection of transport highways or within walking distance to these transport highways. It is obvious that passengers simply will not be interested in the $\mathrm{TIH}$, when the travel time from the TIH to the main transport highways is more than 5-8 minutes by foot. It should also be taken into account that in addition to transport highways, there should be points of attraction for passengers, that will act as points of origin and settlement of passenger traffic.

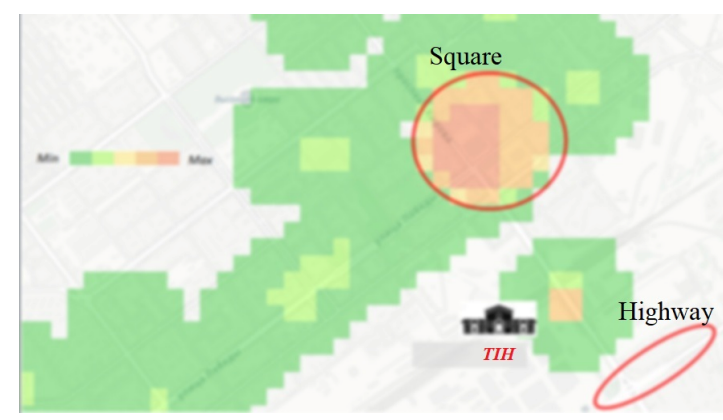

Figure 1: The concentration of trade objects

According to the research conducted by a number of scientists in the modern urban environment, the points of attraction of passengers are large objects of trade, residence places of people, as well as places of their work. To find the optimal location of the $\mathrm{TIH}$, the method of system analysis was used with the decomposition of traffic flows along the main adjacent roads, urban transport routes, by the location of trade 
objects, with the determination of passenger traffic on the main stations adjacent to the location of the TIH. When solving this problem, the simulation modeling tools were also used (Figure 1). As a result, based on the SWOT analysis of possible options for the location of the TIH, one option was selected, which was the most optimal in the existing situation.

\section{Results}

To solve the problem of finding the optimal location, two possible options for the location of the TIH were selected. The first option for the location of the TIH was the option designed by the administration of the city district of Samara. In accordance with the plan, the $\mathrm{TIH}$ is planned to be located on the site of the existing market trade facility and next to the TIH station. With this location of the $\mathrm{TIH}$ and its construction, it will be necessary to demolish the Kirovsky market with its reconstruction and the organization of a suburban bus station. The strengths of this offer are the possibility of building a large intercept parking lot, the active use of a metro station, and the location within walking distance of one of the main highways. The options for placing the TPU are shown in Figure 2 .

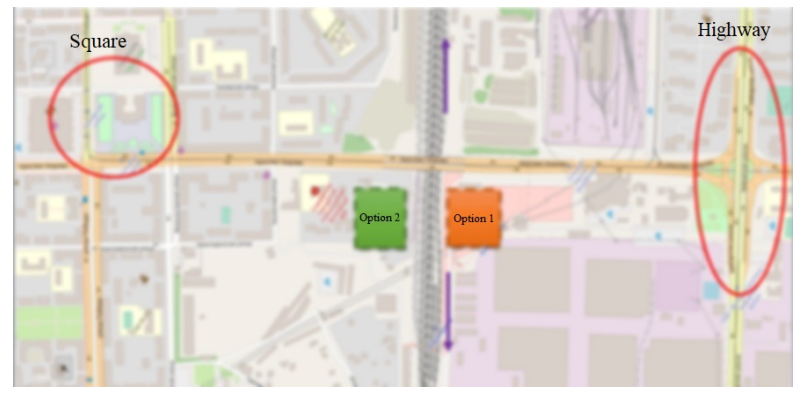

Figure 2: TPU placement options

At the same time, the weaknesses of the location of this option are the following: the expensive purchase of land from the owners of the market, the comparative distance of urban public transport routes (buses, trolleybuses, trams) from the $\mathrm{TIH}$. Walking time from the TIH to the public transport stops is about 10 minutes. The next negative factor is the destruction of the point of passenger traffic attraction in the form of the market trade facility. The distance of the TIH from the existing large interchange stop at the Square, as well as a large trade object in the form of the shopping center. The route of people from the TIH to the shopping center is actually built with the involvement of urban public transport, which will take 10 minutes to walk to. If you use this route to go by foot to the shopping center, then this route will not be safe for passengers. This is due to the fact that the pedestrian will have to cross the railway tracks and then move through an unlit area where there is no pedestrian infrastructure. The location of the $\mathrm{TIH}$ in an industrial area will lead to a clear intraday need for people to migrate. In the morning, people will go to work. In the evening, they will go back. This factor will lead to the fact that after 18 hours, passenger traffic in the TIH area will sharply decrease.

As an alternative option for the location of the $\mathrm{TIH}$, the issue of the TIH location on the opposite side from the Market and the station was worked out. The SWOT analysis of the weaknesses and strengths of the option under consideration allowed to highlight the following strengths. The location of the TIH will be closer to the existing point of attraction for passengers in the form of the shopping center and the Square stop. With the additional development of pedestrian infrastructure near the TIH, the shopping center will be located within walking distance from the TIH. Because of this, even on weekends and in the evening, there will always be a minimum passenger traffic. In fact, the TIH will be located on the border of the residential construction zone. This option preserves the existing trade object - market, as one of the points of passenger traffic attraction. It remains possible to organize the arrival of urban public transport to the $\mathrm{TIH}$, which will reduce the transfer time from one type of transport to another. In addition, the planned site for the $\mathrm{TIH}$ construction in the alternative version is currently abandoned and there is no need for an expensive purchase of land from the owners.

The weaknesses of the suggested option include the distance from the metro station (if you organize a pedestrian bridge or tunnel, the walking distance 
to the metro station will be about 3 minutes). A relatively smaller site for the construction and further development of the TIH. The sizes of the site is actually $40 \%$ smaller than the first option site sizes. Due to the limited available space, there is no possibility of organizing an incentive parking near the TIH.

The analysis of the two options confirms that the common weakness of these options is that the TIH will be located on the side of the railway tracks, which will lead to the need to build a pedestrian bridge. The construction of a pedestrian bridge can lead to certain difficulties for the movement of low-mobility passengers categories. Having considered the two proposed options, it can be noted that the second option of the TIH location is a priority relative to the first option, but the analysis did not consider the directions of passenger traffic and their change in a day or by days of the week. To analyze changes in passenger traffic by periods of the day and days of the week, observations were made of passenger boarding and dropping-off at the nearest stations to the $\mathrm{TIH}$ according to the options [8]. Observations were made at 8 stops, which were located on Square and Avenue, including, and also at the market stop (the future location of the TIH according to option 1). The measurements revealed patterns. The main passenger traffic goes to Square for further transfer to the destination. In the morning, in the peak-activity hour, passenger traffic from Square to the city prevails, and in the evening, on the contrary, from the city to Square with further traffic from the city. The difference between the values of passenger traffic to and from the city is $15 \%$. Of the total number of all arriving passengers on Square, only $30 \%$ arrive from the direction of possible placement of the TIH according to option 1, and only $25 \%$ move in the direction of possible TIH placement. The analysis of the unevenness of passenger traffic over the day period showed that at lunchtime passenger traffic is reduced in some directions by up to $40 \%$, and in some directions the reduction is no more than $5 \%$. The analysis showed a strong migration of the population to the city for jobs and from the city to residence places. According to the results of the study, several conclusions can be drawn.
1. The main passenger traffic will not use the transport interchange hub. In fact, the $\mathrm{TIH}$ will be located away from the main direction of passenger traffic.

2. The fluctuation range of passenger traffic from the TIH and in the direction of the TIH at lunchtime is significantly lower than the fluctuation of passenger traffic that passes the TIH.

Comparison of TPU placement options is shown in Table 1 .

Table 1: Comparison of two options of TPU placement

\begin{tabular}{l|l}
\hline \hline Option 1 & Option 2 \\
\hline $\begin{array}{l}22 \text { minutes to the Square } \\
\text { or } 12 \text { minutes to public } \\
\text { transport }\end{array}$ & $\begin{array}{l}10 \text { minutes to the Square } \\
\text { and public transport }\end{array}$ \\
\hline Market demolition costs & $\begin{array}{l}25 \text { urban public transport } \\
\text { routes }\end{array}$ \\
\hline $\begin{array}{l}17 \text { urban public transport } \\
\text { routes }\end{array}$ & $\begin{array}{l}\text { Pivot area of buses, arrival } \\
\text { of public transport }\end{array}$ \\
$\begin{array}{l}\text { The need for additional } \\
\text { transfers on the square }\end{array}$ & $\begin{array}{l}\text { Provided step-by-step ac- } \\
\text { cessibility to the main } \\
\text { points of "attraction" of } \\
\text { people }\end{array}$ \\
\hline \hline
\end{tabular}

The analysis of the unevenness of passenger traffic on the days of the week showed that the reduction in passenger traffic on weekends reaches $30 \%$ of the passenger traffic on working days. The conclusion is that the morning and evening peak hours of passenger traffic from the TIH and in its direction will be absent. The maximum passenger traffic will be at lunchtime. In the evening, the number of passengers in all directions is sharply reduced, especially in the Avenue at the construction site of the future TIH according to option 1. Based on the results of the analysis, several conclusions can be formulated:

1. Passenger traffic in working days is bigger than on weekends;

2. The main part of the passenger traffic goes to the city, or to the points of attraction, which are the Viva-Land shopping center and the Market; 
3. The planned construction site of the TIH according to option 1 is located away from the main passenger traffic, which was also confirmed by the analysis of the unevenness of passenger traffic during the day.

\section{Conclusion}

After analyzing the values of passenger traffic unevenness by days of the week and periods of the day, the existing street and road network and public transport routes, it can be concluded that the proposed option for the Pyatiletka placement, developed by the Samara city district, contains a number of risks. Ultimately, the proposed $\mathrm{TIH}$ placement (at the Kirovsky market) will affect the further TIH operation. In fact, the suggested option of $\mathrm{TIH}$ placing does not consider the correspondence of passenger traffic on different directions. The proposed territorial TIH location can attract no more than $30 \%$ of the existing passenger traffic. At the same time, the TIH will be located in the industrial zone of the city, which will lead to a significant fluctuation in passenger traffic during the days of the week and in the evening.

There will also be limited opportunities for organizing the arrival of urban public transport in the TIH. To fully organize the arrival/departure of urban transport to/from the $\mathrm{TIH}$, it will be necessary to transfer the final stops of a number of bus routes. This will lead to an increase in the buses running, and as a result, to an increase in the time spent by buses in a road. In addition, it is impossible to organize the arrival of routes of vehicles that move away from the TIH on the main direction of passenger traffic.

There is a difficulty in the development of urban pedestrian infrastructure due to the TIH remoteness from residential areas.

The preliminary calculation of the proposed TIH location according to option 1 (placement at the Kirovsky market), shows that it is not advisable to build a TIH on the planned site.

At the same time, the considered alternative option (option 2) of placing the TIH showed its more favorable position relative to option 1. Significantly less capital investments in the design and construction of the TIH with the possibility of attracting more passengers. The possibility of organizing the arrival of urban public transport, which currently carries up to $60 \%$ of the existing passenger traffic, and the possibility of building urban pedestrian infrastructure located in residential areas.

In order to confirm the theoretical conclusions about the feasibility of placing the TIH according to the alternative option (option 2), simulation TIH models in the ANYLOGIC environment were developed (Ehrlich \& Ehrlich [7]). The experiments also showed the feasibility of $\mathrm{TIH}$ placing on the 2 nd option.

\section{References}

[1] E. I. Danilina, I. Malikova, and D. V. Gorelov, "State and municipal programs to support staff of insolvent public transport companies," Revista Inclusiones, vol. 7, no. 1, pp. 176-189, 2020.

[2] A. Rossolov, V. Naumov, N. Popova, and O. Vakulenko, E. andLevchenko, "Estimation of transport accessibility in case of rational transport hub location," Transport, vol. 36, no. 1, pp. 1-12, 2021. https://doi.org/10.3846/ transport.2021.14299

[3] P. Azami, T. Jan, S. Iranmanesh, and S. Ameri Sianaki, O. Hajiebrahimi, "Determining the Optimal Restricted Driving Zone Using Genetic Algorithm in a Smart City," Sensors (Basel, Switzerland), vol. 20, no. 8, p. 2276, 2020. https://doi.org/10.3390/s20082276

[4] T. Vlasyuk and A. Mikhalchenko, "Analysis of the efficiency of passenger service in transport interchange hubs of the Minsk agglomeration level," Bulletin of the Belarusian State University of Transport: Science and Transport, vol. 2, no. 29, pp. 64-69, 2014.

[5] S. Leonova, "Approaches and methods in the field of creation, development and functioning of transport and transfer hubs," Science and Education of Transport, vol. 1, pp. 99-101, 2017.

[6] I. Volkodaeva and L. Napreenko, "Features of the structure of transport hubs in the urban environment." Bulletin of the International University of Nature, Society and Human "Dubna". Series: Natural and Engineering Sciences, vol. 3, no. 44, pp. 18-23, 2019. https://doi.org/10.37005/1818-0744-2019-3-18-23

[7] A. Ehrlikh and N. Ehrlikh, "Simulation modeling of railway processes," Science and Education to Transport, vol. 1, pp. 119-121, 2017.

[8] A. Ehrlikh and N. Ehrlikh, "Choosing the optimal location of the TIH Pyatiletka based on the analysis of passenger traffic," Science and Education to Transport , vol. 1, pp. 177-180, 2020. 
[9] L. Real, I. Contreras, J. Cordeau, R. de Camargo, and G. de Miranda, "Multimodal hub network design with flexible routes," Transportation Research Part E: Logistics and Transportation Review, vol. 146, p. 102188, 2021. https://doi.org/10.1016/j.tre.2020. 102188

[10] Y. Ke and L. Nie, "Transfer hubs selection of airrail intermodel transport based on ODs classification," Journal of Beijing Jiaotong University, vol. 44, no. 3, pp. 136-141, 2020.

[11] K. Liu, "Research on the transfer space form of railway and subway in transportation hub," Journal of Railway Engineering Society, vol. 37, no. 6, pp. 70-75, 2020.

[12] N. Danilina and S. Privezentseva, "Smart space solutions of pedestrian ways in public transport transit hubs," in IOP Conference Series: Materials Science and Engineering , vol. 775, no. 1, 2021, p. 012008. 